\title{
BAT ECTOPARASITES FROM SINT EUSTATIUS, LESSER ANTILLES (DIPTERA: HIPPOBOSCIDAE: STREBLINAE; HEMIPTERA: POLYCTENIDAE)
}

\author{
John T. Smit ${ }^{1,2}$ and Jeremy Miller ${ }^{2}$ \\ ${ }^{1}$ European Invertebrate Survey, P.O. Box 9517, 2300 RA Leiden, The Netherlands. \\ 2 Naturalis Biodiversity Center, P.O. Box 9517, 2300 RA Leiden, The Netherlands. \\ Correspondence should be sent to Jeremy Miller at: jeremy.miller@naturalis.nl
}

$\begin{aligned} & \text { KEY WORDS } \text { ABSTRACT } \\ & \text { Mammals } \begin{array}{l}\text { In this paper } 4 \text { species of bat ectoparasites are recorded from the island of Sint Eustatius, Dutch } \\ \text { Chiroptera }\end{array} \\ & \text { Caribbean. One species of true bug (Hemiptera: Polyctenidae) as well as } 3 \text { species of bat flies } \\ & \text { Dutch Caribbean } \text { (Diptera: Hippoboscidae: Streblinae) are recorded. All species are photographed. The first DNA } \\ & \text { barcodes for } 3 \text { bat ectoparasite species (Trichobius frequens, Trichobius intermedius, and } \\ & \text { Hesperoctenes fumarius) have been posted to the BOLD database; DNA barcode sequences for a } \\ & \text { fourth species (Megistopoda aranea) are the first from a Caribbean island. }\end{aligned}$

Sint Eustatius is a small island in the northern part of the Lesser Antilles, also known as the Northern Leeward islands. It is in the vicinity of Saba to the northwest and Saint Kitts and Nevis to the southeast and lies south of Sint Maarten. Prior to October 2010 it was a constituent country of the Netherlands Antilles; nowadays it is special municipality of the Netherlands. The island is saddle-shaped, comprised of 2 volcanic areas separated by lowlands, and has an area of $21 \mathrm{~km}^{2}$. The northern hills, called Boven, are covered in dry forest and shrubland generally between 200-300 m elevation whereas the southern part consists of a 600m dormant volcano called the Quill which supports more-diverse lush forest, especially in the crater; this is classified as humid evergreen forest (van Andel et al., 2016).

In 2015, Naturalis Biodiversity Center organized a student field course on Tropical Biodiversity and Field Methods on the island of Sint Eustatius, Lesser Antilles. Members of the Dutch Mammal Society (Zoogdier Vereniging) joined the expedition to conduct a survey of the mammals of the island. During the processing of the netted bats (Mammalia: Chiroptera), they also sampled the ectoparasites, which we present in this paper. The bat records from Sint Eustatius have been published by Pedersen et al. (2018).

The ectoparasites encountered belong to 2 different orders, 1 species of true bug (Hemiptera: Polyctenidae) and 3 species of bat flies (Diptera: Hippoboscidae: Streblinae). Bat flies have been placed classically in 2 closely related families: the Streblidae and Nycteribiidae (Griffiths, 1972; Petersen et al., 2007). However, the monophyly of the Streblidae has not been supported by recent analysis (Kutty et al., 2010). Pape and Thompson (2013) catalog all bat flies within the Hippoboscidae. Despite its dubious monophyly, we continue to use the subfamily Streblinae for the purposes of this paper.

The bat flies of Central and South America are fairly well known, with some major contributions from Panama (Wenzel et al., 1966), Venezuela (Wenzel, 1976) and, more recently, some reviews from Argentina (Autino and Claps, 2000), Honduras (Dick, 2013), and Paraguay (Dick and Gettinger, 2005). The fauna of the West Indies is less well known, especially in the Lesser Antilles. Guerrero (1997) in his catalog reports 26 species from the Caribbean islands. Reeves et al. (2013) described an additional species from St. Kitts. Twentythree of these have been recorded from the Greater Antilles, with the majority originating from Cuba $(n=16)$ and Puerto Rico $(n=$ 8). From the Lesser Antilles only 14 species have been recorded, with Curacao, Dominica, and St. Kitts all having 4 species recorded (Guerrero, 1997; Reeves et al., 2016). In this paper, we report 3 species for the islands of Sint Eustatius, all of which are also known from the neighboring island of St. Kitts.

As for the true bug, Hesperoctenes fumarius was described from Jamaica and is widely distributed in South and Central America, but thus far is only recorded from the Greater Antilles in the West Indies (Ueshima, 1972; Autino and Claps, 2000).

\section{MATERIALS AND METHODS}

The bat survey is described fully by Pedersen et al. (2018), including an overview of the collecting sites (Table I) and hostparasite associations (Table II). Insect specimens were collected 
Table I. Overview of the collecting sites on Sint Eustatius, 9-15 October 2015. Numbers in parentheses refer to map locations in Pedersen et al., 2018; fig. 2 .

\begin{tabular}{ll}
\hline \multicolumn{1}{c}{ Location } & Latitude \\
\hline Oranjestad, swimming pool, kings well (7) & $17^{\circ} 29^{\prime} 9.1^{\prime \prime} \mathrm{N}$ \\
Oranjestad, Mango tree next to airfield (3) & $17^{\circ} 29^{\prime} 25.5^{\prime \prime} \mathrm{N}$ \\
Oranjestad, swimming pool Old Gin House (11) & $17^{\circ} 28^{\prime} 55.3^{\prime \prime} \mathrm{N}$ \\
$\begin{array}{l}\text { Knippenga Estate, swimming pool (24) } \\
\text { The Quill, rim of the crater (21) }\end{array}$ & $17^{\circ} 29^{\prime} 0.8^{\prime \prime} \mathrm{N}$ \\
\hline
\end{tabular}

9-15 October 2015 by Ellen van Norren, Wesley Overman, and Sil Westra (see Pedersen et al., 2018 for more on the bat survey). Several specimens had 1 leg removed for DNA barcoding. Habitus photographs were made using a Nikon DS-Ril camera (Nikon Corporation, Tokyo, Japan) mounted on a Leica M165 C stereoscope (Leica Microsystems, Heerbrugg, Switzerland) operated using NIS Elements software (https://www. nikoninstruments.com/en_EU/Products/Software). Images from multiple focus planes were combined and edited in Syncroscopy Auto-Montage software version 5.03 (http://www.syncroscopy. com). All material has been deposited in the collection of Naturalis Biodiversity Center, Leiden, the Netherlands (Rijksmuseum van Natuurlijke Historie; RMNH).

\section{DNA barcodes}

DNA extraction was done on single legs using the NucleoMag 96 Tissue kit (Macherey-Nagel, Duren, Germany), on a KingFisher Flex magnetic bead extraction robot (Thermo Fisher Scientific, Waltham, Massachusetts), with a final elution volume of $150 \mu \mathrm{l}$. The standard DNA barcoding fragment cytochrome c oxidase subunit I (COI) (Hebert et al., 2003) was amplified using a cocktail of primers LCO1490 (5'-GGTCAACAAATCATAAAGATATTGG-3') and HCO2198 (5'-TAAACTTCAGGGTGACCAAAAAATCA-3') (Folmer et al., 1994) and LepF1 (5'-ATTCAACCAATCATAAAGATATTGG-3') and LepR1 (5'-TAAACTTCTGGATGTCCAAAAAATCA-3') (Hebert et al., 2004). PCR reactions contained $18.75 \mu \mathrm{lmQ}, 2.5 \mu \mathrm{l}$ 10× PCR buffer CL, $1.0 \mu 10 \mathrm{mM}$ of each primer, $0.5 \mu \mathrm{l} 2.5 \mathrm{mM}$ dNTPs, and $0.25 \mu \mathrm{l} 5 \mathrm{U}$ Qiagen Taq, with $1.0 \mu \mathrm{l}$ of template DNA. PCR was performed using an initial denaturation step of $180 \mathrm{sec}$ at $94 \mathrm{C}$ followed by 40 cycles of $15 \mathrm{sec}$ at $94 \mathrm{C}, 30 \mathrm{sec}$ at $50 \mathrm{C}$, and $40 \mathrm{sec}$ at $72 \mathrm{C}$, and finished with a final extension of $300 \mathrm{sec}$ at $72 \mathrm{C}$ and pause at $12 \mathrm{C}$. Bidirectional sequencing was performed at BaseClear (https://www.baseclear. com/). Sequences were edited manually with Sequencher 4.10.1 (Gene Codes Corporation, Ann Arbor, Michigan). For all barcoded specimens, sequences and collection data were uploaded to the Barcode of Life Database (BOLD; http://www.boldsystems.org/). Specimens are linked through their specimen code to their respective entry on BOLD, only SE.2015.1955 and SE.2015.1960 did not produce a barcode sequence.

\section{RESULTS \\ Diptera: Hippoboscidae: Streblinae Megistopoda aranea (Coquillett, 1899)}

(Fig. 1)

Host: All specimens were taken from Artibeus jamaicensis.

Primary host: Artibeus jamaicensis (Wenzel et al., 1966).

Specimens examined: 10 (SE.2015.1961), Oranjestad, swimming pool Old Gin House, 10.x.2015; 10 (SE.2015.1963) 1 우 (SE. 2015.1962), Oranjestad, swimming pool, kings well, 13.x.2015.

Distribution: Widely distributed in South and Central America, within the West Indies previously recorded from Cuba, Puerto Rico, St. Kitts, Montserrat, and Trinidad and Tobago (Gannon and Willig, 1994; Guerrero, 1997; Autino and Claps, 2000; Reeves et al., 2016).

Trichobius frequens Peterson and Hurka, 1974 (Fig. 2)

Host: All specimens were taken from Brachyphylla cavernarum. Primary hosts: Brachyphylla species, known from Brachyphylla cavernarum, Brachyphylla nana, and Brachyphylla pumila (Peterson and Hurka, 1974; Reeves et al., 2016).

Specimens examined: 10 (SE.2015.1957) 2 ㅇ (SE.2015.1955, SE.2015.1956), Oranjestad, Mango tree next to airfield, 14.x.2015.

Distribution: Endemic to the West Indies, described from Cuba and recorded from Dominican Republic and Jamaica (Peterson and Hurka, 1974) and St. Kitts in the Lesser Antilles (Reeves et al., 2016).

\section{Trichobius intermedius Peterson and Hurka, 1974} (Fig. 3)

Host: All specimens were taken from Artibeus jamaicensis. Primary host: Artibeus jamaicensis (Peterson and Hurka, 1974). Specimens examined: 10 (SE.2015.1959), Oranjestad, swimming pool, kings well, 13.x.2015; 2 ㅇ (SE.2015.1958, SE.2015.1960), The Quill, rim of the crater, 15.x.2015.

Table II. Host-parasite associations for the bats sampled on Sint Eustatius, 9-15 October 2015. Higher level taxonomic information given in parentheses.

$$
\text { Bat (Chiroptera) }
$$

Molossus molossus (Molossidae)

Artibeus jamaicensis (Phyllostomatidae)

Brachyphylla cavernarum (Phyllostomatidae)
Ectoparasite

Hesperoctenes fumarius (Hemiptera: Polyctenidae) Megistopoda arenea (Diptera: Hippoboscidae: Streblinae) Trichobius intermedius (Diptera: Hippoboscidae: Streblinae) Trichobius frequens (Diptera: Hippoboscidae: Streblinae) 


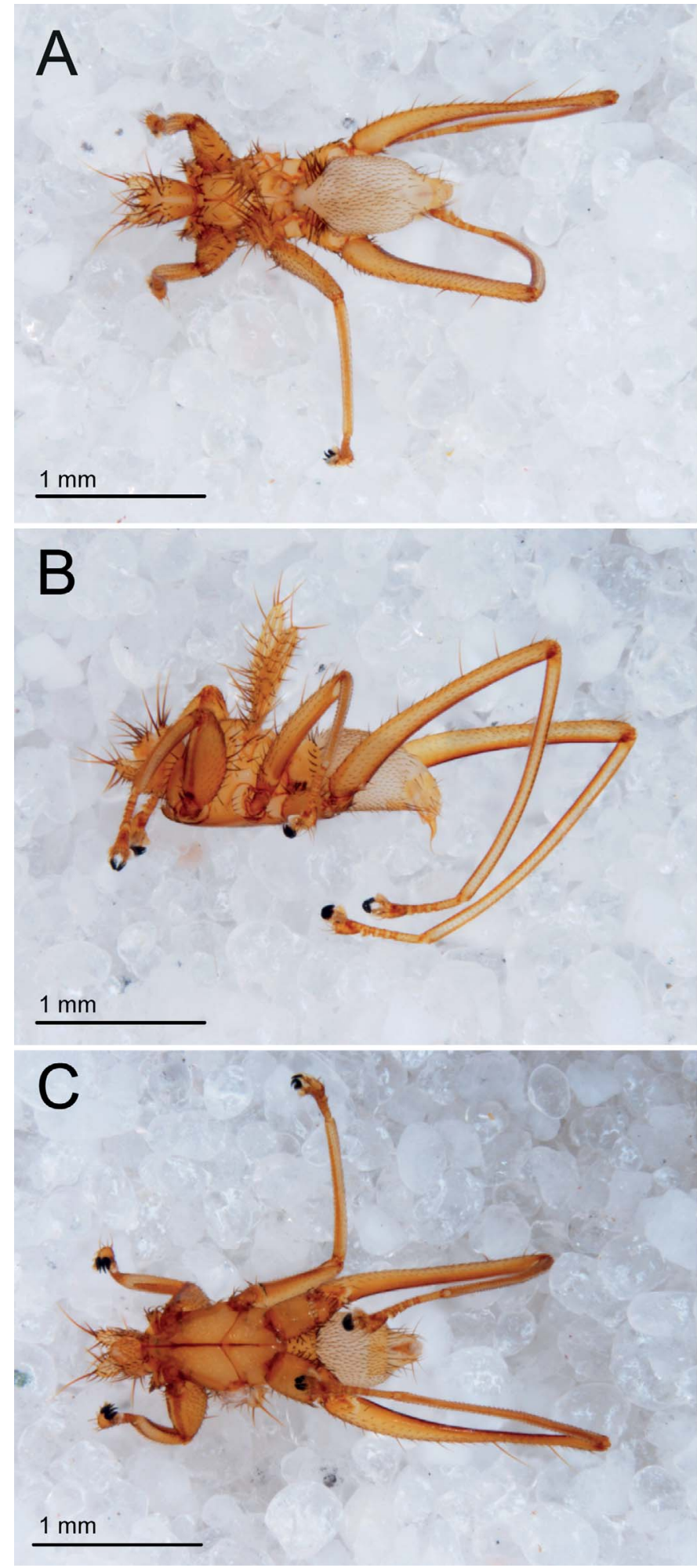

Figure 1. Habitus of male Megistopoda aranea (Diptera: Hippoboscidae: Streblinae) SE.2015.1963. (A) Dorsal view. (B) Lateral view. (C) Ventral view. Color version available online.
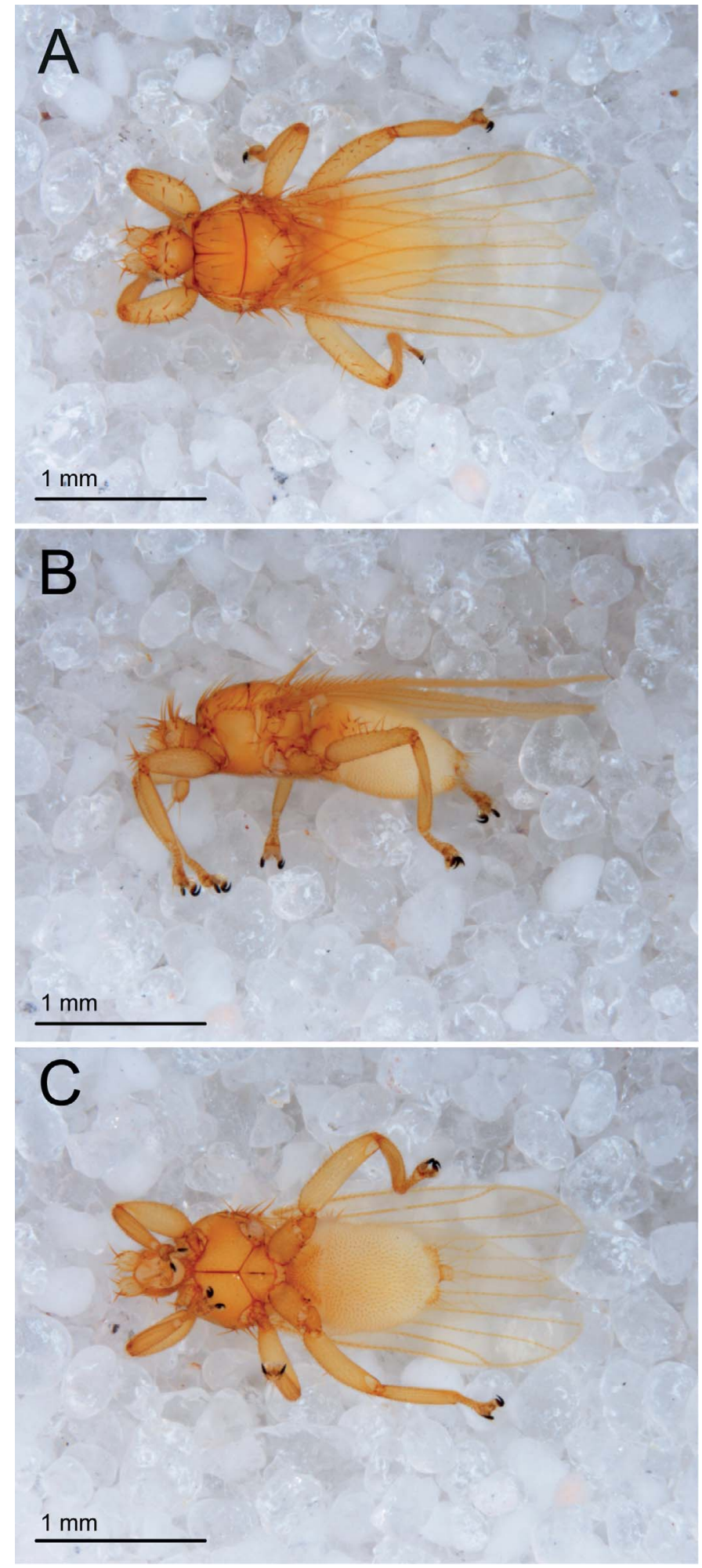

Figure 2. Habitus of female Trichobius frequens (Diptera: Hippoboscidae: Streblinae) SE.2015.1956. (A) Dorsal view. (B) Lateral view. (C) Ventral view. Color version available online. 


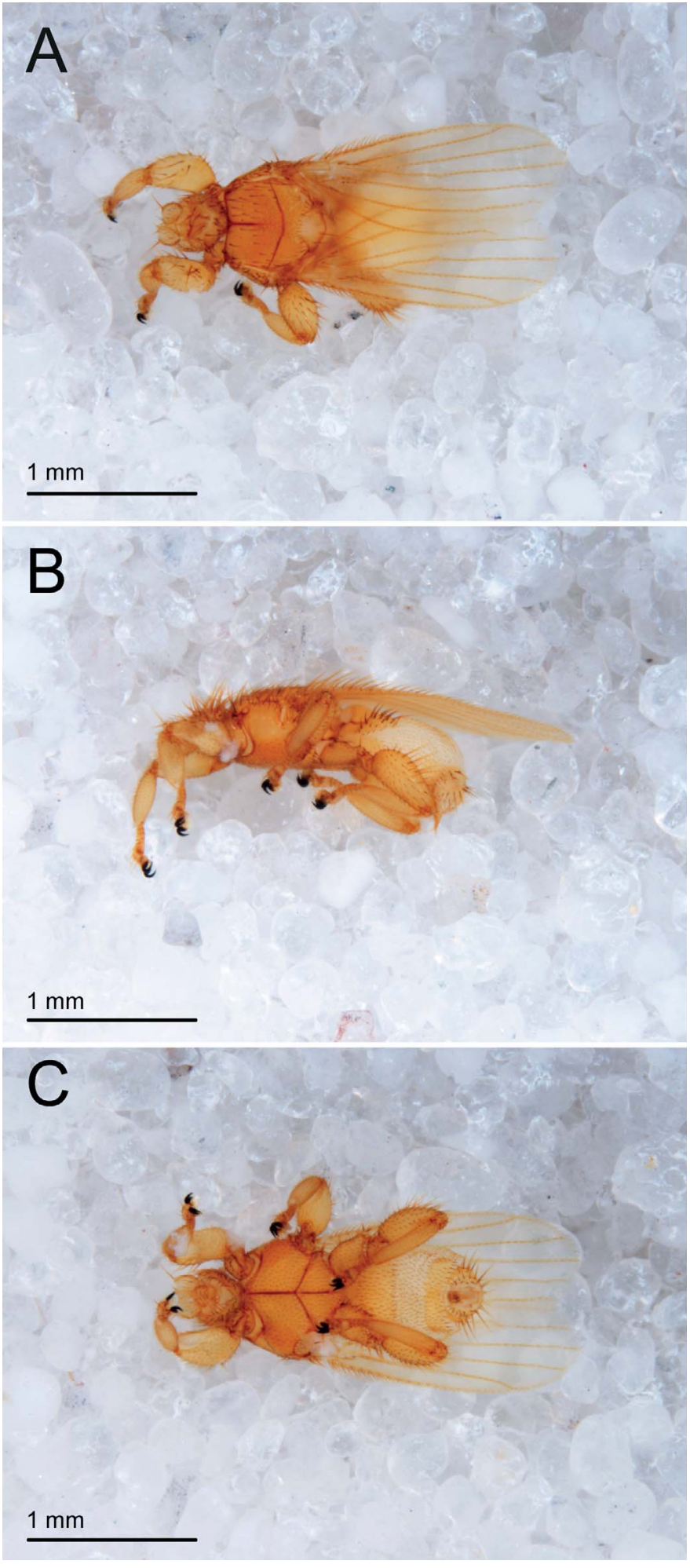

Figure 3. Habitus of male Trichobius intermedius (Diptera: Hippoboscidae: Streblinae) SE.2015.1959. (A) Dorsal view. (B) Lateral view. (C) Ventral view. Color version available online.
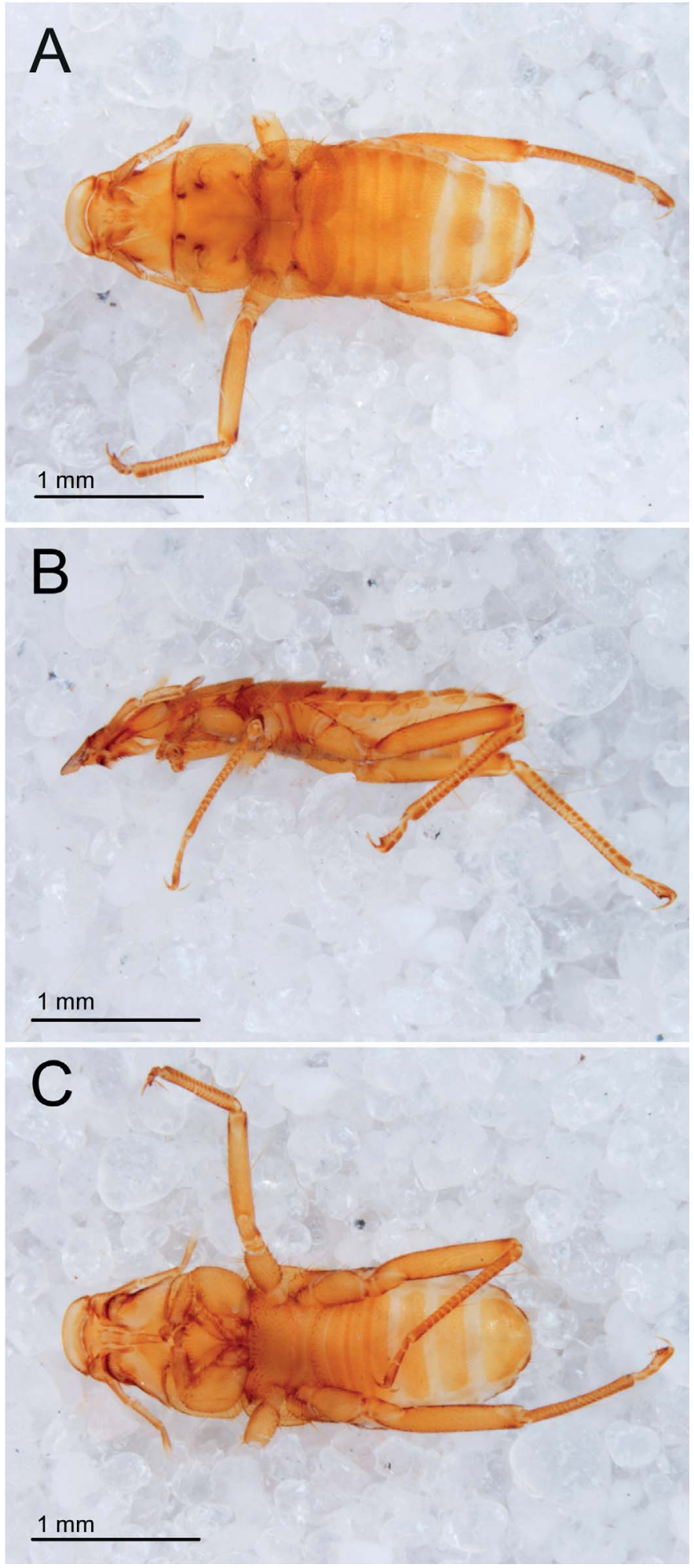

Figure 4. Habitus of female Hesperoctenes fumarius (Hemiptera: Polyctenidae) SE.2015.1949. (A) Dorsal view. (B) Lateral view. (C) Ventral view. Color version available online. 


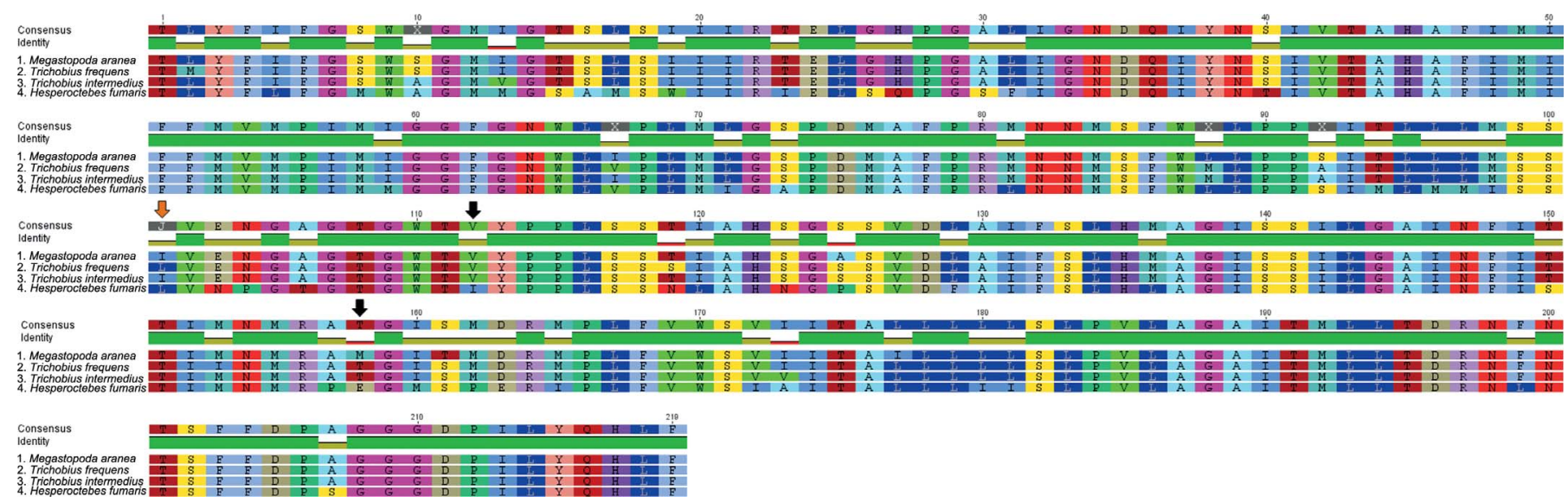

Figure 5. Translated and aligned amino acid sequence based on DNA barcode sequences of Megistopoda aranea, Trichobius frequens, Trichobius intermedius, and Hesperoctenes fumarius (translation frame 2 using invertebrate mitochondrial genetic code) from Sint Eustatius. Arrows indicate heterogeneous positions in amino acid sequence of Megistopoda aranea including those from Central America; orange (light) arrow: 4 of 57 sequences express valine instead of isoleucine at position 101; black arrows: a single sequence (from Petersen et al., 2007) differs from the remaining sequences (isoleucine instead of valine at position 112, lysine instead of methionine at position 158). Color version available online.

Distribution: Widely distributed central America and known from Mexico, El Salvador, Honduras, and Guatemala (Guerrero, 1997). Also widely distributed in both the Greater and Lesser Antilles, in the latter known from St. Martin (Peterson and Hurka, 1974) and St. Kitts (Reeves et al., 2016).

\section{Hemiptera: Polyctenidae Hesperoctenus fumarius (Westwood, 1874)} (Fig. 4)

Host: All specimens were taken from Molossus molossus.

Primary hosts: Molossus species. Known from Molossus rufus (= ater) and Molossus molossus. Ueshima (1972) recorded several other hosts species including three other Molossus species, but due to uncertainty regarding the taxonomic status of these bats at that time, these records should be treated as dubious.

Specimens examined: 2 ㅇ (SE.2015.1952, SE.2015.1953), Knippenga Estate, swimming pool, 9.x.2015; 1 \% (SE.2015.1954), Oranjestad, swimming pool, kings well, 11.x.2015; 3 ㅇ (SE.2015. 1949, SE.2015.1950, SE.2015.1951), same locality, 13.x.2015.

Distribution: Widely distributed in South and Central America, within the Antilles recorded from Cuba, Jamaica, and St. Croix (United States Virgin Islands) (Ueshima, 1972; Autino and Claps, 2000).

Remark: This ectoparasite was not recorded from St. Kitts by Reeves et al. (2016), despite an 11-mo field study, with 99 specimens of Molossus molossus collected.

\section{DNA barcodes}

DNA barcode sequences of 658 base pairs in length were obtained for 13 of the 15 specimens recorded here and representing all 4 ectoparasite species. The sequences are available as a supplementary electronic document (Suppl. Data, Appendix A). Three sequences of Megastopoda aranea were identical. Two sequences of Trichobius frequens differ in 2 positions; the translated amino acid sequences are identical. Two sequences of Trichobius intermedius were identical. Six sequences of Hesperoctenes fumarius are identical except for 1 ambiguous base in specimen SE.2015.1950. The translated amino acid sequence for all 4 ectoparasites is shown in Figure 5. DNA barcode sequences of Megastopoda aranea from other locations have been previously uploaded to DNA sequence databases and will be discussed below; for the remaining ectoparasites, these are the first DNA barcode sequences to be made publically available.

\section{DISCUSSION}

A total of 28 species of bat ectoparasites (Diptera: Hippoboscidae: Streblinae and Nycteribiinae; Hemiptera: Polyctenidae) have been recorded from the West Indies, 11 of which are endemic to these islands (Ueshima, 1972; Guerrero, 1997; Autino and Claps, 2000; Reeves et al., 2013), stressing the hypothesis that the Caribbean is an important biodiversity hotspot as suggested by Myers et al. (2000). This number is likely to increase with further research. For instance, the island of St. Kitts is much smaller than either Curacao or Dominica, yet the same number of bat flies has been recorded from all 3 islands (Guerrero, 1997; Reeves et al., 2016). This suggests that the fauna of much of the islands is still very poorly known, and further fieldwork will reveal additional species and perhaps even new species. For example, Nycterophilia bilineata was recently described from St. Kitts (Reeves et al., 2013) and might turn up on Sint Eustatius as well. The lack of knowledge of the bat ectoparasite fauna from the Lesser Antilles is further illustrated by the first finding of the true bug Hesperoctenes fumarius on Sint Eustatius after just 1 wk of fieldwork. This widespread Neotropical parasite associated with the bat genus Molossus is only sparsely recorded from Caribbean islands. It is remarkable that this species was not encountered by the team of Reeves and colleagues on St. Kitts, who conducted 11 mo of fieldwork and collected some 99 specimens of Molossus molossus, none of which were found to be carrying any ectoparasites.

This work contributed the first DNA barcode sequences available through the BOLD database for 3 bat ectoparasite species: Trichobius frequens, Trichobius intermedius, and Hesperoctenus fumarius. For Megistopoda aranea, several sequences are 


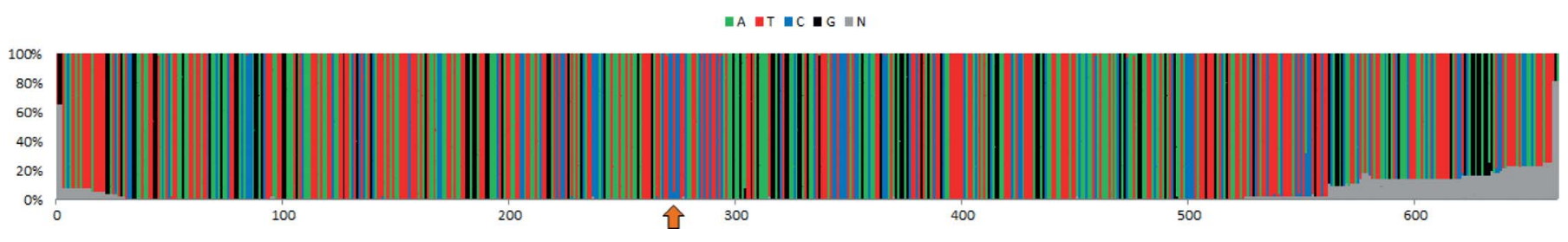

Figure 6. Megastopoda aranea COI barcode base pair sequence heterogeneity based on 57 sequences. Arrow indicates position where specimens from Sint Eustatius differ from all other available sequences in the presence of a $\mathrm{C}$ instead of a $\mathrm{T}$. Color version available online.

currently available from Central American specimens, but the ones presented here are the first from a Caribbean island. A total of 57 records with sequences are currently available through BOLD and GenBank. In addition to the 3 sequences from Sint Eustatius, 6 are from Belize, 30 from Costa Rica, 17 from Panama, and 1 (from Petersen et al., 2007) lacks locality information (Suppl. Data, Appendix B). The specimen from the Petersen et al. (2007) study is quite distinct from all other records. No fewer than 15 sites exhibit a base not found in any other Megastopoda aranea sequence. Viewed using Tree-Based Identification through the BOLD web site, this is the only record of Megistopoda aranea that falls outside the cluster containing the remaining sequences of this species. Instead, this sequence is sister to Megistopoda proxima (7 records from Belize). Other than this, COI sequences of Megastopoda aranea are generally homogeneous (Fig. 6). Specimens from Sint Eustatius are genetically distinct from Central American specimens, most notably due to the presence of a $\mathrm{C}$ at position 271 of the barcode sequences ( $\mathrm{T}$ in the homologous position for all other Megistopoda aranea sequences). This difference represents synonymous codons for the amino acid proline. Neglecting ambiguous codons due to missing base calls, the amino acid sequence for all Megistopoda aranea specimens are identical except one position, which alternatively expresses valine (in 3 Central American specimens plus the specimen from Petersen et al., 2007) or isoleucine (all remaining specimens), plus 2 positions that are identical in all specimens except for the one from Petersen et al. (2007) (Fig. 5).

\section{ACKNOWLEDGMENTS}

The expedition was organized by Berry van der Hoorn, Tinde van Andel, Michael Stech, and Jeremy Miller and funded by Naturalis Biodiversity Center, Leiden, the Netherlands. Fieldwork was facilitated by the Caribbean Netherlands Science Institute (CNSI), Hannah Madden of St. Eustatius National Parks Foundation (STENAPA), and the Dutch Caribbean Nature Alliance. Collecting permits were issued by STENAPA. Ellen van Norren, Wesley Overman, and Sil Westra kindly collected and provided the ectoparasites. Roland Butôt (Naturalis DNA lab) provided substantial assistance with the DNA barcode sequencing. Thanks to editor Richard Clopton and an anonymous reviewer for constructive comments on an earlier draft of the manuscript.

\section{LITERATURE CITED}

Autino, A. G., And G. L. Claps. 2000. Catalogue of the ectoparasitic insects of the bats of Argentina. Insecta Mundi 14: 193-209.
Dick, C. W. 2013. Review of the bat flies of Honduras, Central America (Diptera: Streblidae). Journal of Parasitology Research 2013: 1-18.

Dick, C. W., AND D. GetTinger. 2005. A faunal survey of streblid flies (Diptera: Streblidae) associated with bats in Paraguay. Journal of Parasitology 91: 1015-1024.

Folmer, O., M. Black, W. Hoeh, R. Lutz, and R. Vrijenhoek. 1994. DNA primers for the amplification of mitochondrial cytochrome $\mathrm{c}$ oxidase subunit I from diverse metazoan invertebrates. Molecular Marine Biology and Biotechnology 3: 294-299.

Gannon, M. R., AND M. R. Willing. 1994. Records of bat ectoparasites from the Luquillo Experimental Forest of Puerto Rico. Caribbean Journal of Science 30: 281-283.

Griffiths, G. C. 1972. Phylogenetic classification of Diptera Cyclorrhapha with special reference to the structure of the male postabdomen. Series Entomologica 8: 1-340.

Guerrero, R. 1997. Catalogo de los Streblidae (Diptera: Pupipara) parasitos de murcie'lagos (Mammalia: Chiroptera) del Nuevo Mundo. VII. Lista de especies, hospedadores y paises. Acta Biológica Venezuelica 17: 9-24.

Hebert, P. D. N., A. Cywinska, S. L. Ball, and J. R. deWaard. 2003. Biological identifications through DNA barcodes. Proceedings of the Royal Society B 270: 313-321.

Hebert, P. D. N., E. H. Penton, J. M. Burns, D. H. Janzen, And W. Hallwachs. 2004. Ten species in one: DNA barcoding reveals cryptic species in the Neotropical skipper butterfly Astraptes fulgerator. Proceedings of the National Academy of Sciences 101: 14812-14817.

Kutty, S. N., T. Pape, B. M. Wiegman, and R. Meier. 2010. Molecular phylogeny of the Calyptratae (Diptera: Cyclorrhapha) with an emphasis on the superfamily Oetroidea and the position of Mystacinobiidae and McAlpine's fly. Systematic Entomology 35: 614-635.

Myers, N., R. A. Mittermeier, C. G. Mittermeier, G. A. B. DA FonseCA, AND J. Kent. 2000. Biodiversity hotspots for conservation priorities. Nature 403: 853-858.

Pape, T., ANd F. C. Thompson (eds.).2013. Systema Dipterorum, Version 1.5. Available at: http://www.diptera.org/. Accessed 26 June 2018.

Pedersen, S. C., P. A. Larsen, S. A. Westra, E. van Norren, W. Overman, G. G. Kwiecinski, and H. H. Genoways. 2018. Bats of Sint Eustatius, Caribbean Netherlands. Occasional Papers of the Museum of Texas Tech University 353: 1-24.

Peterson, B. V., And K. Hurka. 1974. Ten new species of bat flies of the genus Trichobius (Diptera: Streblidae). The Canadian Entomologist 106: 1049-1066.

Petersen, F. T., R. Meier, S. N. Kutty, and B. M. Wiegman. 2007. The phylogeny and evolution of host choice in the 
Hippoboscoidea (Diptera) as reconstructed using four molecular markers. Molecular Phylogenetics and Evolution 45: $111-122$.

Reeves, W. K., J. Beck, M. V. Orlova, J. L. Daly, K. Pippin, F. Revan, AND A. D. Loftis. 2016. Ecology of bats, their ectoparasites, and associated pathogens on Saint Kitts island. Journal of Medical Entomology 53: 1218-1225.

Reeves, W. K., A. D. Loftis, AND J. BeCK. 2013. A new species of Nycterophilia (Diptera: Streblidae) from the Antillean fruiteating bat, Brachyphylla cavernarum (Chiroptera: Phyllostomidae). Journal of Entomological Science 48: 114-117.

Ueshima, N. 1972. New world Polyctenidae (Hemiptera), with special reference to Venezuelan species. Brigham Young University Science Bulletin 17: 13-21. van Andel T., B. van der Hoorn, M. Stech, S. Bantjes Arostegui, And J. Miller. 2016. A quantitative assessment of the vegetation types on the island of St. Eustatius, Dutch Caribbean. Global Ecology and Conservation 7: 59-69.

Wenzel, R. L. 1976. The streblid batflies of Venezuela (Diptera: Streblidae). Brigham Young University Science Bulletin 20: 1-177. doi:10.5962/bhl.part.5666.

Wenzel, R. L., V. J. Tipton, And A. Kiewlicz. 1966. The streblid batflies of Panama (Diptera: Calypterae: Streblidae). In Ectoparasites of Panama, R. L. Wenzel and V. J. Tipton (eds.). Field Museum of Natural History, Chicago, Illinois, p. 405-675. 